\title{
DEVELOPMENT AND VALIDATION OF STABILITY-INDICATING HPLC METHOD FOR DIFLUCORTOLONE VALERATE AND ISOCONAZOLE NITRATE COMBINATION
}

\author{
SURIYE ÖZLEM GÜNDOĞDU', FUNDA ŞIMŞEK', ASUMAN DOĞANAY' \\ and YILMAZ ÇAPAN ${ }^{1,2 *}$
}

'İlko R\&D Center, TR-06800 Ankara, Turkey

${ }^{2}$ Hacettepe University Pharmaceutical Technology Department, TR-06800 Ankara, Turkey

\begin{abstract}
The combination of diflucortolone valerate (DIF) and isoconazole nitrate (ISO) is commonly used in pharmaceutical preparations. Though there are already few methods in the literature for the simultaneous determination of these two compounds, none of them involves the stability indicating property that is emphasized by the ICH guidelines. In the present study, a stability-indicating HPLC assay method was developed and subsequently validated for the simultaneous determination of diflucortolone valerate (DIF) and isoconazole nitrate (ISO) in their combined pharmaceutical cream formulations. Separation of active substances and their degradation products was achieved on an ACE column $(150 \times 4.6 \mathrm{~mm}$ id, $5 \mu \mathrm{m}$ particle size $)$ with an isocratic mobile phase of sodium dihydrogen phosphate buffer and methanol mixture in the ratio of $27: 73$, v/v with UV detection at $240 \mathrm{~nm}$. The chromatographic separation was performed in very short run time with a flow rate of 1.5 $\mathrm{mL} / \mathrm{min}$. The developed method was validated as per United States Pharmacopeia (USP) and International Conference on Harmonization (ICH) guidelines. DIF and ISO active substances were exposed to stress conditions separately and also in their combined drug product form in order to examine the stability indicating a property of the proposed method. Stressed samples were analyzed by using HPLC equipped with a photodiode array (PDA) detector and the method was found to be stability-indicating. Therefore, we introduced a facile method for routine analysis of DIF and ISO in combined cream pharmaceutical dosage forms and their corresponding stability studies.
\end{abstract}

Keywords: diflucortolone valerate, isoconazole nitrate, stability indicating method, HPLC analysis

Isoconazole nitrate (ISO) 1-(2,4-dichloro-b(2,6-dichlorobenzyloxy) phenethyl)-imidazole nitrate (Fig. 1b), is a broad spectrum topical antifungal drug. It is effective against dermatophytes, yeasts, yeast-like fungi, molds as well as the causative organism of tinea versicolor and erythrasma. To date, several different analytical methods have been reported for the individual determination of isoconazole nitrate using high-performance liquid chromatography, HPLC $(1,2)$. European Pharmacopeia (EP) proposed potentiometric titration method for assay and liquid chromatography method for its related substances (3). There is also one forced degradation study required for the estimation of stability of ISO in bulk drug and cream formulations (4). However, none of the previously reported methods have stability indicating property.

Diflucortolone valerate (DIF), 6-alpha, 9-difluoro-11beta-hydroxy-21-valeryloxy-16alpha-methyl- 1,4-pregna-diene-3,20-dione (Fig. 1a), is a member of glucocorticoids class III with high efficacy and belongs to a family of medications known as topical corticosteroids. It suppresses inflammation in allergic skin conditions and alleviates the subjective complaints such as itching, burning and pain. According to British Pharmacopoeia (BP) monograph, liquid chromatography method is applied for the determination of assay and related substances of DIF (5). In the literature, HPLC methods have been described for the analysis of DIF in pharmaceutical dosage forms and in its combined form with other substances (6-9).

Combination therapy of an antimycotic and a topical corticosteroid is useful as the steroid component provides rapid symptomatic relief, whereas the antimycotic agent eradicates causative organisms $(10,11)$. Since the combination of DIF and ISO is already being used for treatment of fungal infection

* Corresponding author: e-mail: ycapan@hacettepe.edu.tr 


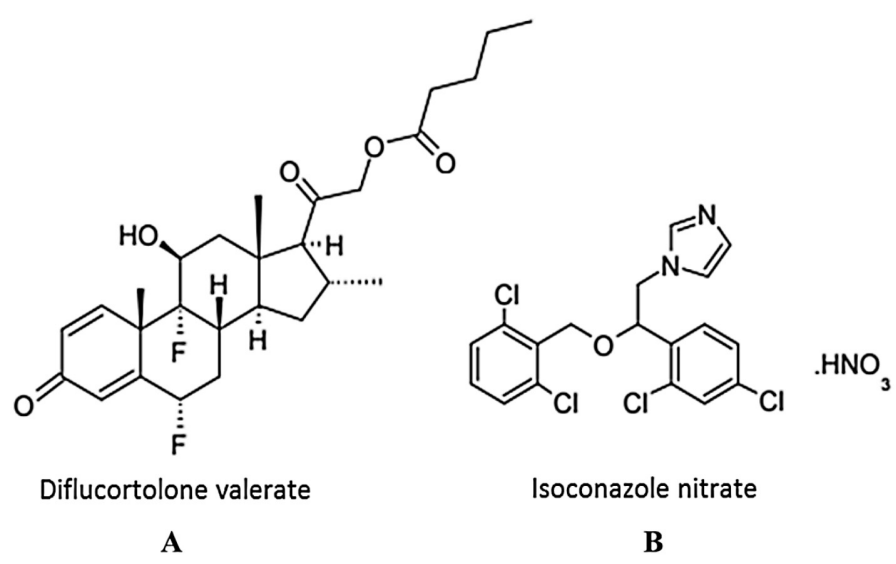

Figure 1. Chemical structures of (A) diflucortolone valerate, (B) isoconazole nitrate

and cutaneous eruption, there is an urgent need for the simultaneous and quantitative determination of these compounds in their binary mixture or in the pharmaceutical preparations free from process impurities, excipients and degradation products. Accordingly, stability indicating method is also needed to probe the changes of the active substances with time, as the chemical stability of pharmaceutical molecules affects the safety and efficacy of the drug significantly. There are already three reported methods using HPLC, TLC, UPLC and spectrophotometry dealing with the first derivative of the drug spectra and PCR chemometric method and also one comparative study on these four spectrophotometric methods manipulating ratio spectra for the simultaneous determination of a binary mixture of diflucortolone valerate and isoconazole nitrate (12-14). However, none of these methods are stability indicating. Notably, the ICH guideline emphasizes the importance of stress test in order to identify likely degradation products, which further helps to determine the intrinsic stability of the drug molecule (15). Therefore, this study was designed to address two major issues: (1) to develop a chromatographic method for the simultaneous determination of DIF and ISO in a combined pharmaceutical form; (2) to measure the stability indicating the ability of the proposed method by applying forced degradation study to a pharmaceutical cream formulation. We have successfully developed and validated a simple, rapid, precise, isocratic RP-HPLC method with a PDA detector in accordance with the requirements of the ICH guidelines for the simultaneous estimation of the ingredients in presence of their degradation products.

\section{EXPERIMENTAL}

\section{Chemicals and reagents}

HPLC grade methanol was purchased from J.T Baker (Deventer, Holland), o-phosphoric acid (85\% $\mathrm{w} / \mathrm{v}$ ) and sodium dihydrogen phosphate were obtained from Merck, Zug, Switzerland and they were used for the preparation of mobile phase. Ultra-pure water was prepared by using Elga Purelab Classic purification system and was used for the preparation of all solutions. Hydrochloric acid (37\% w/v), sodium hydroxide pellets and hydrogen peroxide (30\% w/v) were provided by Merck, Zug, Switzerland, they were used for the forced degradation study. DIF active substance (99.4\%), working standard $(99.3 \%)$ and impurity standard (Diflucortolone impurity, 98.4\%) were supplied by Farmabios SpA (Gropello Cairoli, Italy). ISO active substance $(99.3 \%)$ and working standard $(99.5 \%)$ were provided by Gufic Biosciences Limited (Mumbai, India). Drug product, Travocort cream, was purchased from the market with a label claim of $10 \mathrm{mg}$ Isoconazole Nitrate and $1 \mathrm{mg}$ Diflucortolone Valerate. The excipients of the drug include white soft paraffin, liquid paraffin, cetostearyl alcohol, Polysorbate 60 , sorbitan stearate, disodium edetate dihydrate.

\section{Instrument and chromatographic conditions}

Shimadzu HPLC Prominence System equipped with a PDA (SPD-M20A) detector, DGU-20A degasser, LC-20AT quaternary pump, SIL-20ACHT autosampler and CTO-10AS VP column oven was used for the method development, forced degradation, peak purity, and method validation studies. The 
data was monitored and processed using SHIMADZU LC Solution Software. Chromatographic separations were performed on an ACE C18 column, $150 \mathrm{~mm} \times 4.6 \mathrm{~mm}, 5 \mu \mathrm{m}$ particle size at $40^{\circ} \mathrm{C}$. The flow rate was $1.5 \mathrm{~mL} / \mathrm{min}$. The mobile phase consisted of $0.03 \mathrm{M}$ sodium dihydrogen phosphate monohydrate buffer, $(\mathrm{pH} 2.7 \pm 0.05)$ and methanol with a ratio of $27: 73, \mathrm{v} / \mathrm{v}$. Methanol and water mixture $(70: 30, \mathrm{v} / \mathrm{v})$ was used as a diluent and the injection volume was $20 \mu \mathrm{L}$. Detection wavelength of the chromatographic system was set to $240 \mathrm{~nm}$ and autosampler temperature was $8^{\circ} \mathrm{C}$.

\section{Preparation of diflucortolone valerate stock stan- dard solution}

The stock DIF solution was prepared by dissolving $10 \mathrm{mg}$ standard in $10 \mathrm{~mL}$ of methanol in an ultrasonic bath for about 5 minutes and then diluting to $20 \mathrm{~mL}$ with methanol.

\section{Preparation of standard solution}

$10 \mathrm{mg}$ of ISO working standard was weighed and transferred into a $100 \mathrm{~mL}$ volumetric flask and dissolved using $50 \mathrm{~mL}$ of diluent in an ultrasonic bath for 10 minutes. After cooling to room temperature, $2.0 \mathrm{~mL}$ of DIF stock standard solution is transferred into this solution. Then, the mixture is diluted to the desired volume with diluent.

\section{Preparation of sample solutions}

Approximately $1000 \mathrm{mg}$ of a cream sample containing $1.0 \mathrm{mg}$ of DIF and $10.0 \mathrm{mg}$ of ISO was dissolved in $60 \mathrm{~mL}$ of diluent by keeping the solution in an ultrasonic bath for 20 minutes (Note: prevent the heating of sample by maintaining the water temperature and close the beaker tightly with an aluminum foil). This mixture was transferred into a $100 \mathrm{~mL}$ of volumetric flask and diluted to volume with diluent. Then, the solution is filtered through a $0.45 \mu \mathrm{m}$ nylon filter and transferred to the HPLC vial.

\section{Procedure for forced degradation study of drug product and drug substances}

Forced degradation studies of a drug product and each drug substances were carried out under acid/base hydrolysis, photolysis, thermal and oxidative stress conditions. About $1000 \mathrm{mg}$ of a drug product and $10 \mathrm{mg}$ of each drug substances were separately used to perform degradation studies.

\section{Acid and Alkaline Hydrolysis}

Solutions containing $0.01 \mathrm{mg} / \mathrm{mL}$ DIF and $0.1 \mathrm{mg} / \mathrm{mL}$ ISO were subjected to $0.05 \mathrm{~N} \mathrm{HCl}$ and $0.05 \mathrm{~N} \mathrm{NaOH}$ for $2 \mathrm{~h}$ at ambient temperature, respectively. Then, the $\mathrm{pH}$ of the solutions was rearranged to an initial $\mathrm{pH}$ of a drug product (4.6).

\section{Oxidative degradation}

Solutions containing $0.01 \mathrm{mg} / \mathrm{mL}$ DIF and $0.1 \mathrm{mg} / \mathrm{mL}$ ISO were treated with $30 \% \mathrm{H}_{2} \mathrm{O}_{2}$ solution at room temperature for $6 \mathrm{~h}$. Then the solutions were heated to boil for 5 minutes. After cooling, the solutions were diluted to volume.

\section{Thermal degradation}

Thermal degradation studies were carried out with solid samples in a temperature controlled oven at $80^{\circ} \mathrm{C}$ for 5 days. After the specified time, the solutions containing $0.01 \mathrm{mg} / \mathrm{mL}$ DIF and $0.1 \mathrm{mg} / \mathrm{mL}$ ISO were prepared and each sample was analyzed to observe the possible degradation products.

\section{Photolysis}

Solid samples were kept under UV light for $5 \mathrm{~h}$ at room temperature and solutions containing 0.01

Table 1. Optimized chromatographic conditions.

\begin{tabular}{|l|c|}
\hline Parameters & Conditions \\
\hline Mobile phase & Sodium dihydrogen phosphate buffer $:$ methanol $(27: 73, \mathrm{v} / \mathrm{v})$ \\
\hline Pump mode & Isocratic \\
\hline Diluent & ACE C18 column $(150 \times 4.6 \mathrm{~mm} \mathrm{id}, 5 \mu \mathrm{m}$ particle size $)$ \\
\hline Column & $40^{\circ} \mathrm{C}$ \\
\hline Column oven temperature & $240 \mathrm{~nm}$ \\
\hline Wavelength & $20 \mu \mathrm{L}$ \\
\hline Injection volume & $1.5 \mathrm{~mL} / \mathrm{min}$ \\
\hline Flow rate & $10 \mathrm{~min}$ \\
\hline Run time & Diflucortolone valerate: $3.6 \mathrm{~min}$; Isoconazole nitrate: $6.2 \mathrm{~min}$ \\
\hline Retention time & \\
\hline
\end{tabular}


$\mathrm{mg} / \mathrm{mL}$ DIF and $0.1 \mathrm{mg} / \mathrm{mL}$ ISO were prepared to observe the effect of photolysis.

\section{Method validation}

The method was validated for specificity and selectivity, linearity and range, limit of detection (LOD) and limit of quantification (LOQ), precision, accuracy, robustness, and solution stability as per FDA guidelines $(16,17)$.

\section{Specificity and Selectivity}

For the specificity and selectivity test, working standards, spiked/unspiked sample solutions, placebo and mobile phase solutions were injected into HPLC and resolution of the peaks from the nearest eluting peak was measured. In addition, system suitability was checked to evaluate the chromatographic performance.

\section{Linearity}

Linearity of the method was determined by preparing a series of diluted solutions in the concentration range of 2-12 $\mu \mathrm{g} / \mathrm{mL}$ for DIF and 20-123 $\mu \mathrm{g} / \mathrm{mL}$ for ISO. The samples of each solution were injected 2 times and each series comprised 6 experimental points. Then, the concentrations were plotted against peak areas.

\section{Limit of Detection and Limit of Quantification}

LOD and LOQ values were determined by the standard deviation method from the slope $(\mathrm{S})$ of the linearity curve and the standard deviation $(\sigma)$ of the response. They were predicted using following formulas; $\mathrm{LOD}=3.3 \times \sigma / \mathrm{S}$ and $\mathrm{LOQ}=10 \times \sigma / \mathrm{S}$.

\section{Accuracy}

Accuracy for the proposed method was evaluated by spiking constant amount of placebo a with known amount of active substances by the standard addition method. The experiment was carried out by adding each active substance corresponding to three concentration levels $(2 \mu \mathrm{g} / \mathrm{mL}, 10 \mu \mathrm{g} / \mathrm{mL}, 12 \mu \mathrm{g} / \mathrm{mL}$ for DIF; $20 \mu \mathrm{g} / \mathrm{mL}, 100 \mu \mathrm{g} / \mathrm{mL}, 120 \mu \mathrm{g} / \mathrm{mL}$ for ISO) for using three replicate determinations. The percent recovery values were calculated.

\section{Precision}

Precision was determined as both repeatability (intra-day precision) and intermediate precision (inter-day precision). Method repeatability was evaluated by analyzing six samples during the same day. The intermediate precision was studied comparing the assays performed on two different days. From the areas obtained, the \% relative standard deviation (RSD) values were calculated for each active substance.

\section{Robustness}

The influence of small but deliberate variations in the chromatographic conditions was evaluated by performing the robustness test on the system. The robustness of the method was determined by changing the flow rate $1.5 \pm 0.1 \mathrm{~mL} / \mathrm{min}(1.4 \mathrm{~mL} / \mathrm{min}-$ $1.6 \mathrm{~mL} / \mathrm{min})$, mobile phase buffer ratio $(27 \pm 2)$ and column temperature $40 \pm 2^{\circ} \mathrm{C}\left(38^{\circ} \mathrm{C}-42^{\circ} \mathrm{C}\right)$. For each substance, the effect of change on retention time, symmetry factor and \% assay value were evaluated.
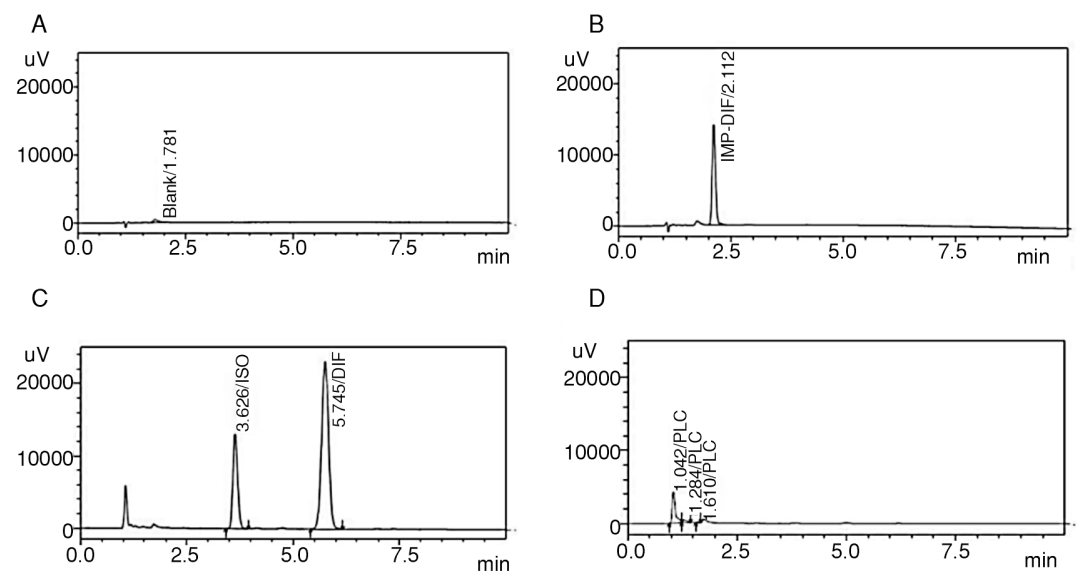

Figure 2. Specificity chromatograms of (A) blank (composed of 70 volumes of methanol and 30 volumes of water), (B) diflucortolone impurity solution $\left(t_{R}=2.11 \mathrm{~min}\right.$.), (C) sample solution $\left(t_{R}=5.74 \mathrm{~min}\right.$. for DIF and $t_{R}=3.63 \mathrm{~min}$. for ISO) (D) placebo solution 


\section{Solution stability}

The stability of the active substances in solution was established by the repeated analysis of samples at the storage condition. For this purpose, standard and sample solutions were analyzed in chromatographic conditions for every $6 \mathrm{~h}$ interval for a time period of $48 \mathrm{~h}$. The results were evaluated for the percent difference from time zero.

\section{RESULTS AND DISCUSSION}

\section{Optimization of the method}

The main objective of the developed method is to achieve simultaneous and quantitative determination of DIF and ISO in topical formulations in the presence of their degradation products by using reverse phase HPLC system. For this purpose, chromatographic behaviors of degradation products and active substances were studied in a combined dosage form.

Before starting the method development, various physiochemical properties of drugs like $\mathrm{pKa}$ value, $\log \mathrm{P}$, solubility and absorption maximum were evaluated to optimize the HPLC method. Log P and solubility values help to select mobile phase and sample solvent while $\mathrm{pKa}$ value helps to determine the $\mathrm{pH}$ of the mobile phase (18). In semisolid formulations, the choice of diluent is critical to guarantee that all the active substances are extracted from the matrices. For this purpose, different ratios of water:acetonitrile and water:methanol mixtures were studied. The extraction of the active components from a sample with good recovery was achieved by using water:methanol mixture (30:70, v/v) as diluent.

For the optimization of stationary phase, several reversed phase columns [Fortis C18 $(4.6 \times 250$ $\mathrm{mm}, 2.7 \mu \mathrm{m}), \mathrm{ACE} \mathrm{C} 18(4.6 \times 250 \mathrm{~mm}, 5 \mu \mathrm{m}), \mathrm{ACE}$ C8 $(4.6 \times 250 \mathrm{~mm}, 5 \mu \mathrm{m})$, Phenomenex Luna C18 $(75 \times 4.6 \mathrm{~mm}, 2.6 \mu \mathrm{m})$, ACE C18 $(4.6 \times 150 \mathrm{~mm}$, $5 \mu \mathrm{m})$ and Inertsil ODS-3V C18 (4.6 × $250 \mathrm{~mm}$, $5 \mu \mathrm{m})$ ] were tested. When C8 columns were used, peak fronting was observed for both ISO and DIF with a very low theoretical plate number. To improve the peak shapes, an attempt was made by replacing the $\mathrm{C} 8$ column with $\mathrm{C} 18$, which led to better performance characteristics for both active drugs. Therefore, ACE C18 $(150 \times 4.6 \mathrm{~mm}, 5 \mu \mathrm{m})$ column was chosen as the stationary phase. Afterward, different mobile phase systems were tested, and the selection of the proper system depended on its ability to give good separation between the pure drugs and their possible degradation products. Several mobile phases were tried using various proportions of water and methanol. While increasing the propor- tion of the aqueous phase led to the adequate separation of the peaks, it caused prolonged retention times and peak tailing particularly for DIF. To obtain better peak shapes and efficient resolution between the degradation products and active drugs, sodium dihydrogen phosphate buffer solution was used as an aqueous phase instead of water. The $\mathrm{pH}$ of the buffer

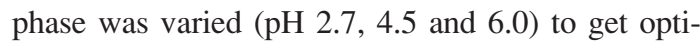
mum separation between the possible degradation products of DIF and ISO in stressed samples. When the buffer $\mathrm{pH}$ is arranged to 6.0, specified degradation product (diflucortolone impurity) was coeluted with DIF. Then, the $\mathrm{pH}$ value was set to 4.5 , this time adequate resolution was achieved for all degradation products, however, this has led to prolonged retention times. When the buffer solution witha a $\mathrm{pH}$ value of 2.7 was tried, it provided both well-resolved peaks and short run time; therefore, $\mathrm{pH} 2.7$ was selected for the subsequent studies.

The wavelength selection was done by injecting known concentrations of DIF, ISO and diflucortolone impurity to HPLC system equipped with a PDA detector. A common wavelength for the simultaneous determination of all the components was selected as $240 \mathrm{~nm}$ by overlaying the spectra and wavelength at which all components had significant absorbance.

Finally, an isocratic method was employed using a buffer (Sodium dihydrogen phosphate, $\mathrm{pH}$ 2.70 ), and methanol in the ratio of $27: 73 \mathrm{v} / \mathrm{v}$ as a mobile phase. The flow rate of the system was set to $1.5 \mathrm{~mL} / \mathrm{min}$ with $40^{\circ} \mathrm{C}$ column oven temperature. Since the solution stability is provided at $8^{\circ} \mathrm{C}$ for 48 hours, autosampler temperature was set to $8^{\circ} \mathrm{C}$ to prevent possible degradation of active substances in solution. Detection wavelength of the system was chosen as $240 \mathrm{~nm}$. Separation of the compounds was achieved by ACE C18 $(150 \times 4.6 \mathrm{~mm}, 5 \mu \mathrm{m})$ column with $20 \mu \mathrm{L}$ injection volume. Optimized chromatographic conditions are summarized in Table 1. By using corresponding chromatographic conditions; diluent, standard solution, sample, spiked sample, and placebo solutions were prepared and injected into the HPLC (Fig. 2).

Stress testing of individual drug substances and the combined dosage form was performed to measure the resolution factors of the drug peaks from all other peaks. Identification of stressed samples resulted in one specified (diflucortolone impurity; RRT 0.34 ) and one unspecified degradation product (RRT 0.41 ) for DIF and one unspecified degradation product (RRT 0.82) for ISO. The degradation products produced as a result of stress study did not interfere with the detection of active substances. Therefore, 
the developed method could be regarded as stability indicating. The results of the analysis were fully validated. Thus, the method is suitable for application in the routine analysis of pharmaceutical formulations consisting of ISO and DIF in combination.

\section{Analytical method validation}

Validation of test parameters was performed to verify the quantitative determination of method, after ensuring the optimal separation conditions. Based on (USP/ICH) guidelines, the method is validated with regard to system suitability, specificity, linearity, LOD and LOQ, accuracy, precision, and robustness as follows.

\section{System suitability}

System suitability parameters were measured to verify the system, method, and column performance.
The \% RSD values for six replicate injections of DIF and ISO standard solutions were 1.06, and 1.35, respectively. Low values of \% RSD indicates that the system is precise. The tailing factors for both DIF and ISO peaks were 1.1. The efficiency of the column was proved in terms of a number of theoretical plates. All the results and acceptance criteria for the system suitability test are summarized in Table 2.

\section{Specificity}

The active substances, placebo, and impurity peaks were observed without any overlapping in the chromatogram indicating the specificity of the method (Fig. 2).

\section{Method precision}

RSD less than $2 \%$ is generally accepted for precision so it was set as an acceptance criterion for

Table 2. System suitability results.

\begin{tabular}{|c|c|c|c|}
\hline \multirow{2}{*}{ Substance } & \multicolumn{3}{|c|}{ System suitability } \\
\cline { 2 - 4 } & Area (\%RSD, $\mathrm{n}=6)$ & USP Plate count & USP tailing \\
\cline { 2 - 4 } & $\begin{array}{c}\leq 2.0 \\
\text { acceptance criteria }\end{array}$ & $\begin{array}{c}>2000 \\
\text { acceptance criteria }\end{array}$ & $\begin{array}{c}\text { acceptance criteria } \\
\text { actan }\end{array}$ \\
\hline DIF $^{\mathrm{a}}$ & 1.06 & 5226 & 1.10 \\
\hline ISO $^{\mathrm{b}}$ & 1.35 & 4609 & 1.09 \\
\hline
\end{tabular}

aiflucortolone valerate, ${ }^{\mathrm{b}}$ Isoconazole nitrate

Table 3. Intra-day and inter-day precision $(n=6)$ results.

\begin{tabular}{|c|c|c|c|c|c|c|c|}
\hline \multirow[b]{2}{*}{ Substance } & \multirow{2}{*}{$\begin{array}{l}\text { Theoretical } \\
\text { Concentration } \\
(\mu \mathrm{g} / \mathrm{mL})\end{array}$} & \multicolumn{3}{|c|}{ Repeatibility (Intra-day) } & \multicolumn{3}{|c|}{ Intermediate precision (Inter-day) } \\
\hline & & $\begin{array}{c}\text { Recovery } \\
(\%)\end{array}$ & $\begin{array}{c}\text { Measured } \\
\text { concentration } \\
(\mu \mathrm{g} / \mathrm{mL}) \pm \text { S.D. }\end{array}$ & $\%$ RSD & $\begin{array}{c}\text { Recovery } \\
(\%)\end{array}$ & $\begin{array}{c}\text { Measured } \\
\text { concentration } \\
(\mu \mathrm{g} / \mathrm{mL}) \pm \text { S.D. }\end{array}$ & $\%$ RSD \\
\hline $\mathrm{DIF}^{\mathrm{a}}$ & 10 & 101.87 & $10.19 \pm 1.28$ & 1.26 & 102.64 & $10.26 \pm 0.59$ & 0.57 \\
\hline $\mathrm{ISO}^{\mathrm{b}}$ & 100 & 101.39 & $101.39 \pm 0.61$ & 0.60 & 99.31 & $99.31 \pm 1.56$ & 1.57 \\
\hline
\end{tabular}

a Diflucortolone valerate, ${ }^{\mathrm{b}}$ Isoconazole nitrate, S.D. Standard deviation

Table 4. Results of recovery test for drug product.

\begin{tabular}{|c|c|c|c|}
\hline \multicolumn{2}{|c|}{ Concentration $(\mu \mathrm{g} / \mathrm{mL})$} & \multicolumn{2}{|c|}{ \% Recovery* $^{*}$} \\
\hline $\mathrm{DIF}^{\mathrm{a}}$ & $\mathrm{ISO}^{\mathrm{b}}$ & $\mathrm{DIF}^{\mathrm{a}}$ & ISO $^{\mathrm{b}}$ \\
\hline 2.0 & 20.0 & 98.7 & 101.7 \\
\hline 10.0 & 100.0 & 98.8 & 100.5 \\
\hline 12.0 & 120.0 & 98.1 & 100.7 \\
\hline \multicolumn{2}{|r|}{ mean standard deviation } & 98.5 & 0.91 \\
\hline \multicolumn{2}{|r|}{$\%$ relative standard deviation } & 0.92 & 0.91 \\
\hline
\end{tabular}

*Average of three determinations, ${ }^{\text {a }}$ Diflucortolone valerate, ${ }^{\mathrm{b}}$ Isoconazole nitrate 


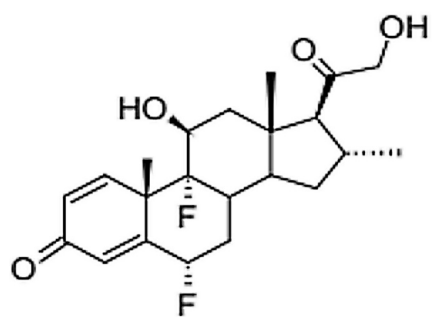

Table 5. Forced degradation study conditions.

\begin{tabular}{|c|c|}
\hline Applied Stress & Stress conditions, duration \\
\hline Acid hydrolysis & $0.05 \mathrm{~N} \mathrm{HCl}, 2 \mathrm{~h}$ \\
\hline Base hydrolysis & $0.05 \mathrm{~N} \mathrm{NaOH}, 2 \mathrm{~h}$ \\
\hline Oxidative degradation & $30 \%(\mathrm{v} / \mathrm{v}) \mathrm{H}_{2} \mathrm{O}_{2}, 6 \mathrm{~h}$ \\
\hline Thermal degradation & $80^{\circ} \mathrm{C}, 5$ days \\
\hline Photodegradation & UV light, $5 \mathrm{~h}$ \\
\hline
\end{tabular}

Figure 3. Chemical structure of diflucortolone impurity

A

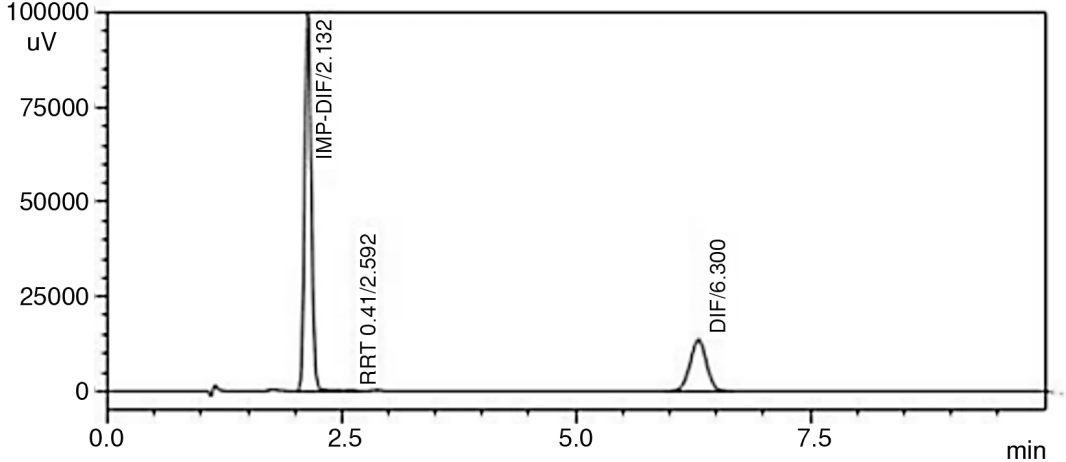

B
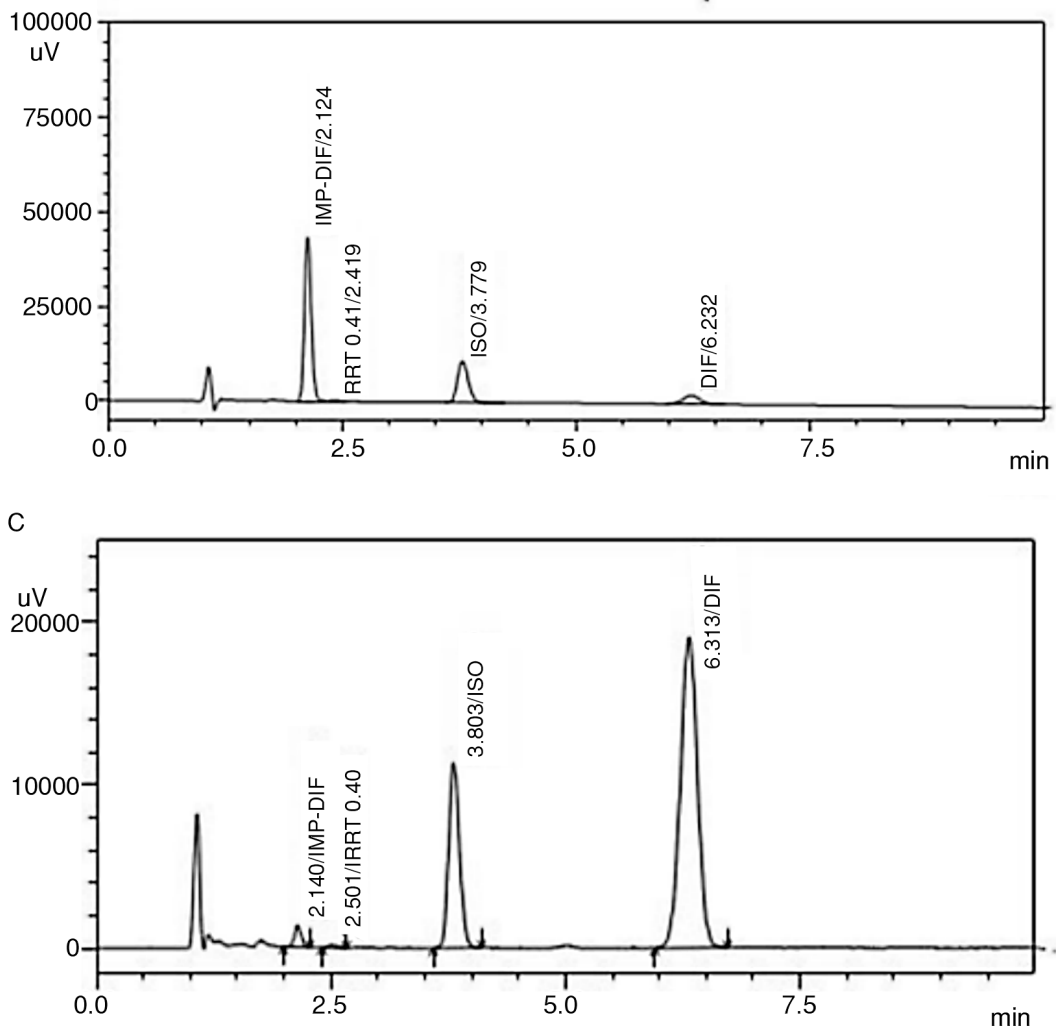

Figure 4. Chromatograms of forced degradation study; (A) Acid degradation (0.05 mol/L HCI; $298 \mathrm{~K} ; 2$ h) of diflucortolone valerate drug substance, (B) Acid degradation $(0.05 \mathrm{~mol} / \mathrm{L} \mathrm{HCI} ; 298 \mathrm{~K} ; 2 \mathrm{~h})$ of drug product, (C) base degradation $(0.05 \mathrm{~mol} / \mathrm{L} \mathrm{NaOH} ; 298 \mathrm{~K} ; 2 \mathrm{~h})$ of drug product 
A

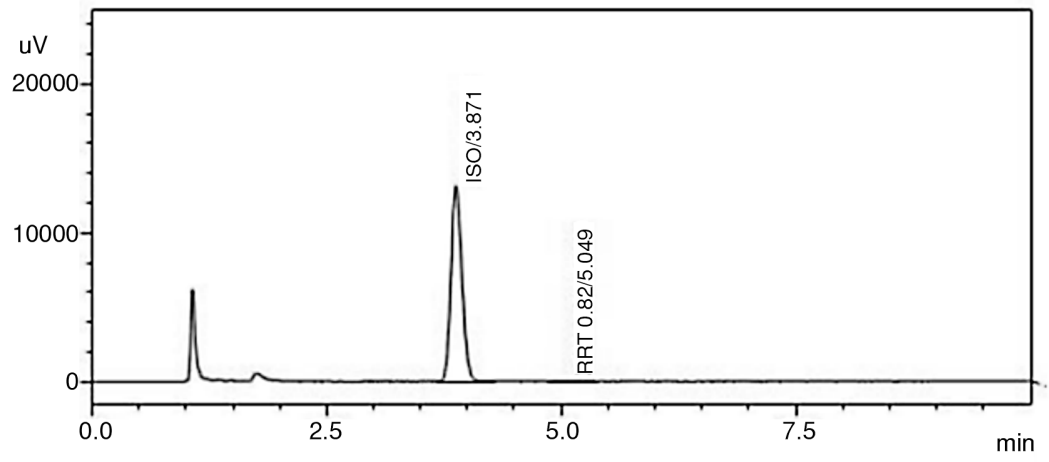

$\mathrm{B}$

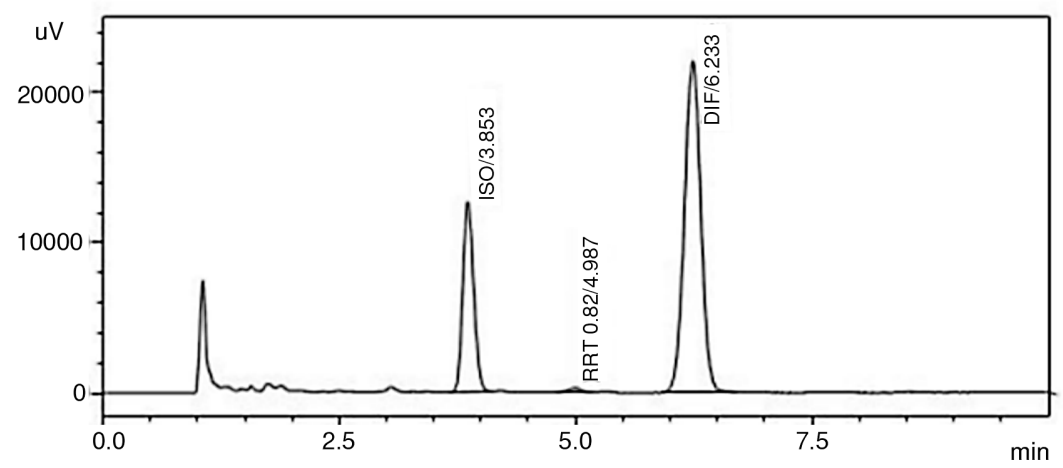

Figure 5. Chromatograms of forced degradation study; Photolysis degradation (under UV light; $298 \mathrm{~K} ; 5$ h) of (A) isoconazole nitrate drug substance, (B) drug product

this study (16). From the assay results obtained, \% RSD values were calculated as 1.26 and 0.60 for DIF and ISO, respectively. The results are within the limits $(\mathrm{RSD}<2)$, indicating high precision of the developed method (Table 3).

\section{Accuracy}

Percentage recovery and low relative standard deviation values show accuracy of the method (17). Generally acceptable values for accuracy range from 95-105\%. The recovery values for DIF and ISO ranged from $98.1 \%$ to $98.8 \%$ and $99.8 \%$ to $101.7 \%$, respectively, demonstrating that the method is accurate within the desired range. The results are shown in Table 4.

\section{Linearity}

According to the guidelines, regression coefficient $\left(\mathrm{R}^{2}\right)$ of each active substance should be $=0.999$ for linearity (17). Linear calibration curves of each drug were obtained over the calibration ranges 2-12 $\mu \mathrm{g} / \mathrm{mL}$ for DIF and $20-123 \mu \mathrm{g} / \mathrm{mL}$ for ISO. The calibration curves described by the equations were as folows; $y=27.127 \times-0.00176\left(R^{2}=0.999\right)$ for $\mathrm{DIF}$ and $y=0.970 \times-0.000863\left(R^{2}=1.000\right)$ for ISO. Since regression coefficients for both drugs are higher than 0.999 , response is linear over the proposed range.

\section{Limit of detection and limit of quantification}

LOD and LOQ values were estimated from the linear calibration curve method (16). Under applied chromatographic conditions, the LOD of DIF was $0.2 \mu \mathrm{g} / \mathrm{mL}$ and LOQ of DIF was $0.6 \mu \mathrm{g} / \mathrm{mL}$. LOD and LOQ of ISO were $1.0 \mu \mathrm{g} / \mathrm{mL}$ and $4.0 \mu \mathrm{g} / \mathrm{mL}$ respectively.

\section{Robustness}

There were no significant changes in the retention time, area and symmetry of peaks obtained with the robustness tests. It demonstrates that the developed method has resistance to variances in chromatographic conditions since the results obtained were within the specification limits.

\section{Solution stability}

The solution stability results showed that peak areas of DIF and ISO remained approximately same 
up to $48 \mathrm{~h}$ and no significant degradation within the indicated period was observed. This indicates that sample solutions were stable at $8^{\circ} \mathrm{C}$ up to $48 \mathrm{~h}$.

\section{Stability indicating property of the method}

The stability indicating property of the developed method was evaluated by applying forced degradation procedure to both active substances and drug product. Our first aim was to evaluate the source of unspecified degradation products obtained in the stress study of the drug. For this purpose, each active substance was initially exposed to different stress conditions (Table 5) to investigate their possible degradation products and test their chromatographic behavior.

Following this test, the drug product was subjected to acid and base hydrolysis, oxidation, thermal and humidity degradation conditions and the products of forced degradation were evaluated. The degraded amount was calculated by subtracting the recovered amount in each stress condition from the recovered amount of unspiked samples. There was no detected specified/unspecified impurity above the reporting level in the unspiked drug product.
During acid hydrolysis of a drug product, while ISO was observed to be stable, $87.8 \%$ of DIF was degraded. The main degradation product of DIF was diflucortolone impurity, $6 \alpha, 9 \alpha$-difluoro- $16 \alpha-$ methyl-1,4-pregnadiene-11ß,21-diol-3,20-dione, (Fig. 3, Diflucortolone impurity) at $2.1 \mathrm{~min}$.

Under base hydrolysis conditions, DIF degradation showed an additional unspecified degradation product at RRT of 0.41 in addition to diflucortolone impurity. In the case of ISO, no degradation was observed under basic condition (Fig. 4).

Under the oxidative degradation condition, both DIF and ISO were found to be stable since no additional peaks were detected upon treatment with $30 \% \mathrm{H}_{2} \mathrm{O}_{2}$

During the photolysis process, the samples were exposed to UV light for 5 hours. This process led to the degradation of about $2.4 \%$ of ISO verified by the appearance of degradation product at RRT of 0.82 , while DIF was found to be stable under the same condition (Fig. 5).

After exposing the drug to $80^{\circ} \mathrm{C}$ for 5 days, ISO was found to be stable. Although the extent of

A

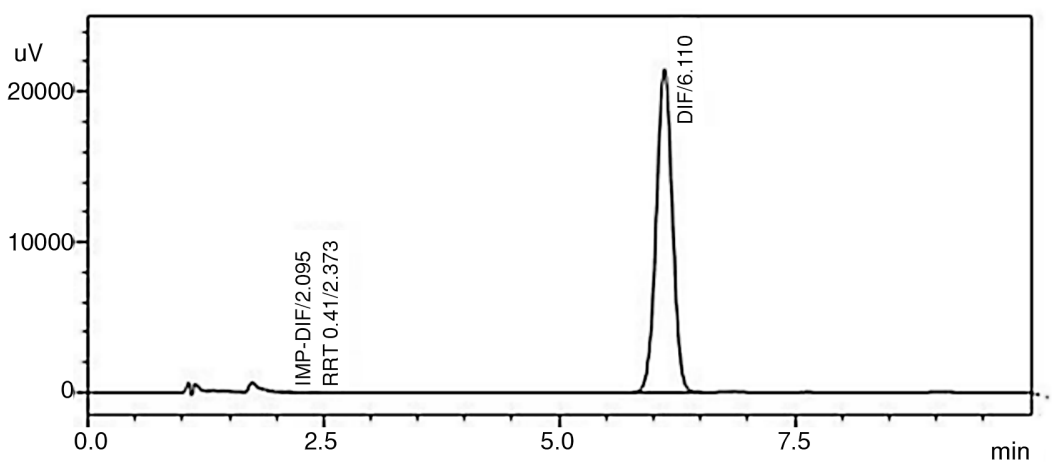

B

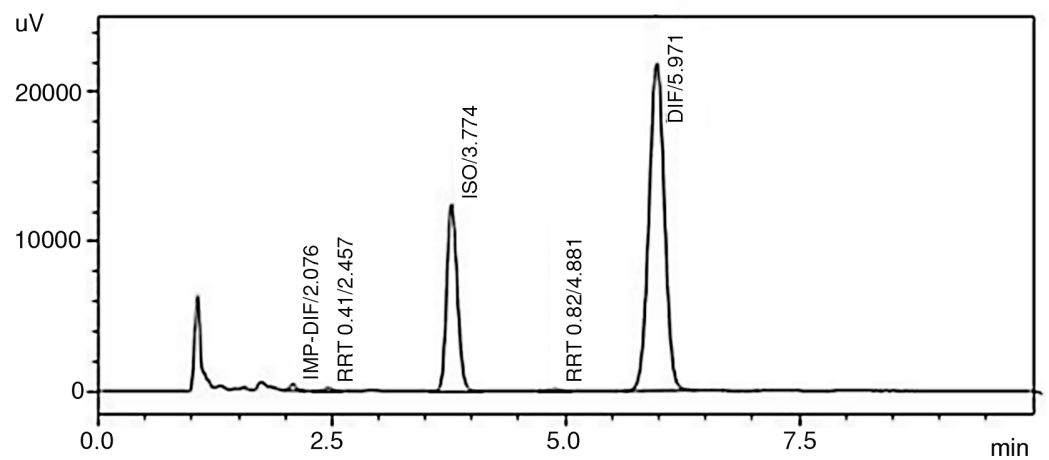

Figure 6. Chromatograms of forced degradation study; Thermal degradation ( $353.15 \mathrm{~K}$ for 5 days) of (A) diflucortolone valerate drug substance, (B) Drug product 
degradation for DIF was not significant, a small amount of diflucortolone impurity and unspecified degradation product of RRT 0.41 formation was confirmed by the respective chromatograms (Fig. 6). To prove the stability-indicating power of the method; peak purities were checked for ISO, DIF and all degradation products by using a PDA detector in stress samples. Peak purity test results confirmed that all the peaks obtained from the stressed samples were homogeneous and pure. Peak purity index values are summarized in Table 6.

For the calculation of mass balance ( $\%$ assay + $\%$ degradation products), assay of the stressed samples was performed for comparison to the reference standard. The mass balance for the stressed samples was close to $100 \%$ (Table 6) proving that there was no overlapping between active substances and degradant peaks. Therefore, it was confirmed that the assay of DIF and ISO was unaffected by the presence of degradation products.

\section{CONCLUSION}

Identification, quantification and control of impurities in the drug substance and drug product, are an important part of drug development and regulatory assessment. Accordingly, a simple, rapid and stability-indicating RP-HPLC method was successfully developed for the estimation of DIF and ISO in their topical pharmaceutical combination. The proposed method made use of PDA detector as a tool for peak identity and purity confirmation. The method validation results have proven that the method is selective, precise, accurate, linear and robust. Forced degradation data revealed that the method is free from the interference of placebo, specified and unspecified degradation products. The developed method is stability indicating and this property makes it superior to other previously published HPLC methods. Thus, the described method is suitable for routine analysis and quality control of pharmaceutical preparations containing these drugs either individually or in a combined dosage form.

\section{Acknowledgments}

The authors are thankful to İLKO İlaç San ve Tic. A.Ş. for providing necessary facilities used in our research studies. We also thank Prof. Ali Coskun for his kind contribution.

\section{REFERENCES}

1. Di Pietra A.M., Cavrini V., Andrisano V., Gatti R.: J. Pharm. Biomed. Anal. 10, 873 (1992).

2. Ozen G., Gumustas M., Kara H.E.S., Goger N.G., Uslu B., Ozkan S.A.: Rev. Roum. Chim. 60, 527 (2015).

3. "European Pharmacopoeia" $7^{\text {th }}$ Ed., Council of Europe, Strasbourg 2008.

4. Ahna A.V., Santos J.H.Z.D.: Anal. Methods 4, 2404 (2012).

5. "British Pharmacopeia”, Her Majesty's Stationery Office, London 2004.

6. Maeda Y., Owada K., Yamamoto M., Sato S., Masui T.: Shizuoka-ken Eisei Kankyo Senta Hokoku 30, 35 (1987).

7. Maeda Y., Owada K., Yamamoto M., Sato S., Masui T., Nakazawa H.: Bunseki Kagaku 37, 648, (1988).

8. Gagliardi L., De Orsi D., Del Giudice M.R., Gatta F., Porra R., Chimenti P.: Anal. Chim. Acta 457, 187 (2002).

9. Palabıyık I.M., Asan D., Onur F.: J Food Drug Anal. 15, 145 (2007).

10. Veraldi S., Persico M.C., Schianchi R.: J Drugs Dermatol, 11, e70 (2012).

11. Veraldi S.: Mycoses 56, 3 (2013).

12. Karacan E., Caglayan M.G., Palabiyik I.M., Onur F.: J. Assoc. Off. Anal. Chem. 94, 128 (2011).

13. Fayez Y.M., Elghobashy M.R., Goda Z.M., Shehata M.A.: Bull. Fac. Pharm. Cairo Univ. 54, 39 (2016).

14. Fayez Y.M., Elghobashy M.R., Goda Z.M., Shehata M.A.: Bull. Fac. Pharm. Cairo Univ. 54, 33 (2016).

15. ICH Harmonised Tripartite Guideline, Stability Testing of New Drug Substances and Products Q1A (R2), ICH, Geneva, Switzerland 2003.

16. ICH Harmonised Tripartite Guideline, Validation of Analytical Procedures: Text and Methodology Q2(R1) current step 4 version, 2005.

17. The United States Pharmacopeia, USP-37, NF $32<1225>$ Validation of Compendial Procedures.

18. Bakshi M., Singh S.: J. Pharm. Biomed. Anal. 28, 1011 (2002).

Received: 11.05. 2018 